\title{
E-Banking: Benefits and Issues
}

\author{
Dr. Hajera Fatima Khan \\ Accounting Department, College of Business Administration, University of Hail, Hail, \\ Kingdom of Saudi Arabia \\ hajeratameem48@gmail.com
}

Received Date: March 03, 2017

Accepted Date: March 7, 2017

Published Date: May 30, 2017

Abstract: E-Banking has become an important factor in the future development of banking industry. Electronic banking or online banking is a service provide by many banks that allow handling of all types of banking business, primarily over the internet by using the information technology and communication. In many developed countries E- banking plays a very vital role due to the fact that it's the cheapest way of providing banking services. Beside this it also facilitated swift movement of funds domestically and across borders. E-Banking is one of the most successful on-line businesses, which save the time and money of customers and companies. It is easily accessible anywhere to a PC, PDA, mobile device, with an internet connection. It also enables the customer to conduct financial transactions on the website of the institution, such as virtual bank, retail bank, a credit union etc. Despite of many benefits of E-Banking, there are some factors which affect its usage. This research paper will introduce you to e-banking, giving the meaning, functions, types, advantages and issues. In short e-banking is anytime and anywhere banking.

Keywords: E-Banking, E-Commerce, Information Technology, Customer Satisfaction, etc.

\section{INTRODUCTION}

\section{Electronic Banking}

The term "Electronic Banking" or "Internet banking" is defined as a remote banking services provided by the authorized banks, or their representatives through devices operated either under the bank's direct control or management or under the outsourcing agreement. In other words, e-banking is an umbrella term for the process by which a customer may perform banking transactions electronically without visiting a branch and also includes the systems that enable customers of banks, individuals or businesses, to access accounts, transact business, or obtain information on financial products and services through a public or private network, including the Internet. E-Banking definition would include situations where a foreign bank provides e-banking products or services to residents in a foreign country from:

A. A location in the bank's home country or

B. An "onshore" physical establishment in another foreign country.

The terms which are used to describe the various forms of e-banking are ,personal computer (PC) banking; Internet banking; virtual banking; online banking; home banking and remote electronic-banking. E-banking also involves phone banking and the use of automated teller machines (ATMs). 
What is electronic banking?

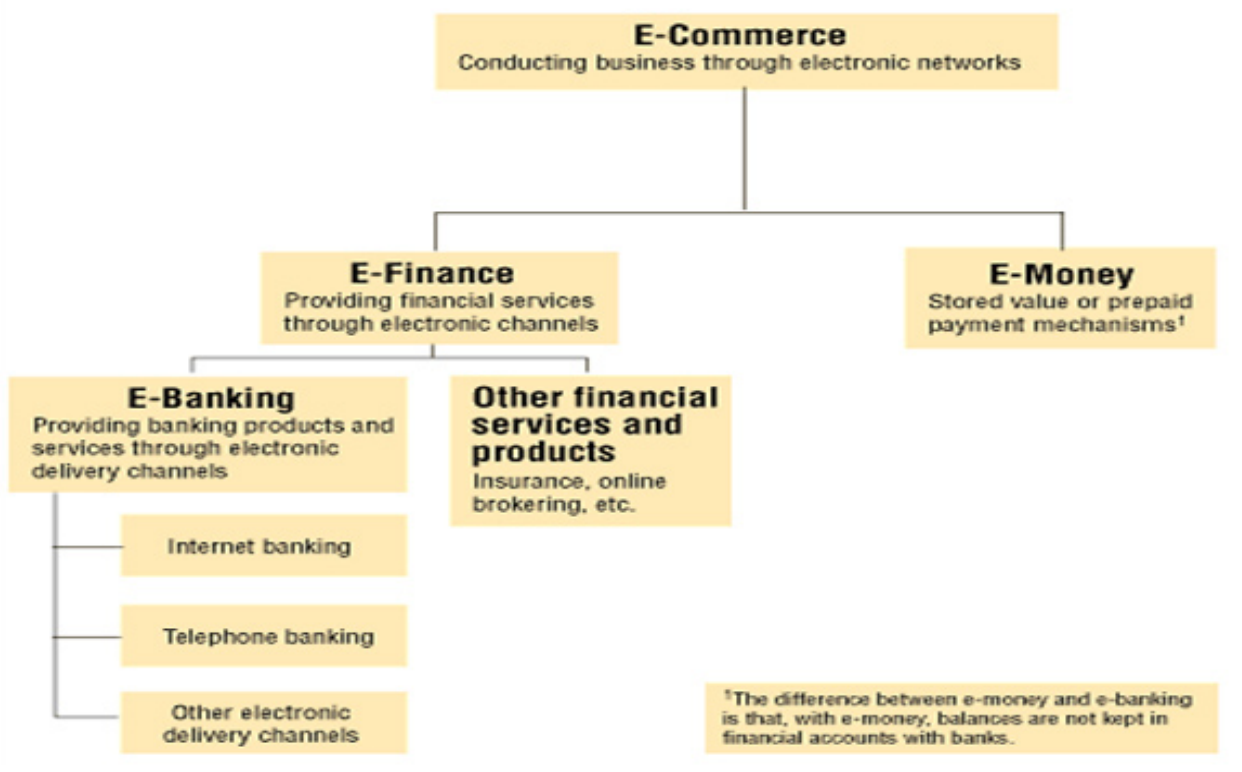

Figure 1

\section{E- Banking features}

A. A bank customer can perform non transactional task through online banking by :
a. Viewing account balances.
b. Viewing last transactions.
c. Downloading bank statement.
d. Viewing images of cheques paid.
e. Requesting for the issuance of new cheque book.
f. Downloading periodic account statements.
g. Downloading applications for mobile banking, electronic banking etc.

B. Bank customers can perform banking task through online banking by:
a. Transferring funds between the customers linked account, national transfers and international transfers.
b. Purchasing and selling of investments.
c. Loan applications and transactions, such as repayments of enrolments.
d. Credit card transactions.
e. Registering and payments of utilities bills.

C. Beside the above banking task a bank customer can also perform other task such as:

a. Financial institution administration.

b. Management of multiple users having varying levels at authority. 


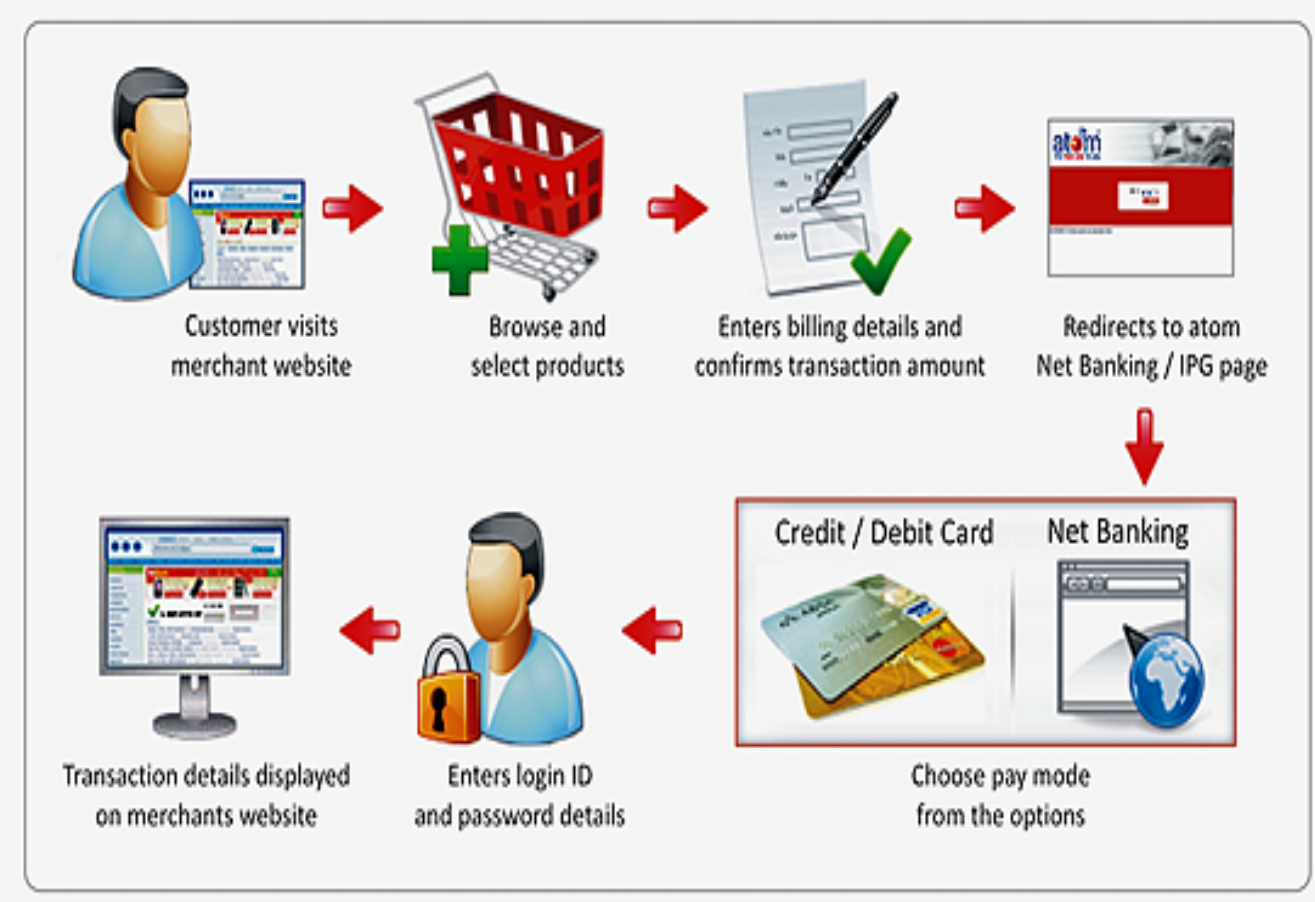

Figure 2

\section{E-BANKING OBJECTIVES RULES AND SERVICES}

\section{Objectives}

The main objectives of the "E-Banking Rules" are as under:

A. The main objective of e-banking rule is to provide guidance to banks on implementation of security controls in their e-banking products, services and effective management of risks associated.

B. The e-banking rules are not aimed to discouraging banks from innovation and creativity .It mainly ensures on customer's facilitation.

\section{Rules}

The main "E-Banking Rules" are as under:

In order to enable banks to protect customers' information, reduce fraud incidents, and manage e-banking related risks as also to minimize the number of complaints from the e-banking users, SAMA (Saudi Arabian Monetary Agency) has decided to issue new "E-Banking Rules". These Rules will replace the "Internet Banking Security Guidelines" issued in the year 2001.

The new E-Banking Rules are risk-based and set out SAMA's prudential regulatory approach to the supervision of e-banking services. They provided guidance to banks on risk management in electronic banking and emphasized on:

A. Board of directors and senior management accountability. 
B. Customer protection and education.

C. Customer privacy.

D. Minimum security standards consistent with best international standards.

E. Proper incident management and reporting to SAMA.

F. Proper availability management.

G. Capacity building and business continuity planning.

Banks are expected to review and, if required, to modify their existing risk management policies and processes to bring their e-banking activities in line with these Rules.

\section{Services}

"E-Banking" offers various services to its customers the most common services are as under:

A. Transactional Activities like transfer of funds, payment of bills, loan applications and other transactions.

B. No transactional activities like request for issuing of cheque book stop or make payments, online statements, updating the contact information of a customer.

\section{RESEARCH METHODOLOGY}

The primary source of the information in this research study is the secondary data. The available information on internet regarding the E: Banking has been extensively used to complete this paper. Beside this the study also completed by making the use of various sources related to the subject of study like research articles, scientific journals, websites, and some banking and e-banking books.

\section{OBJECTIVES OF THE STUDY}

The key intention of this paper is to evaluate those factors to manipulate the nature of customer towards E- banking and there growing tendency towards the online financial institutions.

A. To get full acquaintance of E- banking and its prospects.

B. To get full acquaintance of E-Banking Objectives, Rules and Services.

C. To know the benefits of E-banking.

D. To know the issues of E-banking.

E. To make suggestions on the basis of findings.

\section{BENEFITS OF INTERNET BANKING}

The benefits discussed below are from the bank's customer's point of view .By the use of e-banking services a customer can save its significant time and money. These kinds of services also bring efficiency in customer relationship management (CRM).

\section{Services}

Technology has made it extremely convenient for the bank and for the customer to access easily by simply logging in on the banks website. e-services include vast services such as financial planning capabilities, functional budgeting and forecasting tools, loan calculators, investment analysis tools and equity trading platforms.Beside this most banks also provide the facility of online tax forms and tax preparation. 


\section{Convenience}

This is the single most important benefits that outweigh any shortcoming of internet banking. Making transactions and payments right from the comfort of home or office at the click of a button without even having to step out is a facility none would like to forego. Keeping a track of accounts through the internet is much faster and convenient as compared to going to the bank for the same. Even non transactional facilities like ordering check books online; updating accounts, enquiring about interest rates of various financial products etc is much simpler by it.

\section{Better Rates}

This means that a portion of savings accrued by the bank can be passed on to the customers in by paying them higher rates on deposits and charging lower rates on loans. To encourage e- banking among customers most banks offer minimum or no deposit accounts and also charges lower penalties on early withdrawal of Fixed Deposits. This type of banking implies lesser physical efforts and higher benefits. The need to acquire larger spaces for offices and employee more staff to deal with the customers is significantly reduced making it financially beneficial to the banks.

\section{Mobility}

E- banking has a step further in the last few years in the form of mobile internet banking which accords unlimited mobility to the customer who can now handle financial transactions even while on the move.

\section{Increased comfort and timesaving}

E-Banking transactions can be made $24 * 7$, without requiring the physical interaction with the bank.

\section{Quick and continuous access to information}

Corporations will have easier access to information as, they can check on multiple accounts at the click of a button.

\section{Better cash management}

E-banking facilities speed up cash cycle and increases efficiency of business processes as large variety of cash management instruments are available on Internet sites of Estonian banks.

\section{Speed}

The response of this medium of transaction is very fast; therefore customers can actually wait till the last minute before transferring the funds.

\section{Funds management}

Customers can download their transactions history of different accounts and do a "what-if" analysis on their own, before affecting any transaction on the web. This leads to better funds management.

Beside the above benefits discussed E-banking also helps to view and print balance enquiry, view transaction history, transfer of funds, payment of online utility bills, online purchases etc. With the use of E-banking customer can also apply for various types of auto, mortgage, home, equity, students or personal loans.

\section{ISSUES OF E- BANKING}

Besides providing enormous benefits to its customers in terms of the ease of cost transactions, e-banking also possess certain issues in regulating, supervising, designing and implementing the macroeconomic policies by 
creating problems for bank management, regulatory and supervisory authorities. They originate not only for potential or cross border transactions but also for domestic transactions which are based upon technology applications which causes many security related issues.

\section{Relationships}

Online transactions take a toll on the relationship with the banker which the traditional visit to the branch office used to foster. Personal relationship with the staff at the banks helps a customer when requesting for faster loan approval or any special service which may not be available easily to the public. Additionally by personal contact a banker would provide essential financial advices which are beneficial to the customer.

\section{Complex Transactions}

Certain services such as notarization and bank's signature cannot be accomplished online. Solving specific issues and complaints requires physical visit to the bank and cannot be achieved through the internet.

\section{Security}

This is the biggest pitfall of the internet banking scheme which needs to be guarded against by the common customer. Despite the host of sophisticated encryption software is designed to protect your account there is always a scope of hacking by smart elements in the cyber world. Hacker attacks, phishing, malware and other unauthorized activity are common on the net.

\section{The ability to adopt global technology to local requirements}

An adequate level of infrastructure and human capacity building are required before developing countries can adopt the global technology for their local requirements.

\section{The ability to strengthen public support for e-finance}

Historically, most e-finance initiatives in developing countries have been the result of cooperative efforts between the private and public sectors.

\section{CONCLUSION}

The present Study concludes that e-banking has fundamentally changed the business of banking by providing immense opportunities to its customers. It is a border less entity permitting anytime, anywhere and anyhow banking to its customers. On the other hand it also aggravates the use of traditional banking risk. In the present scenario majority of the customers are accepting online banking transactions because of its many favorable factors. There is a significant relationship between e- banking and customer satisfaction. The customers are committed to using the service, as well as banks is able to retain the major interest of its users. Beside the enormous benefits e-banking is a difficult business and face a lot of challenges like usefulness, security and privacy. Many customers think that it is not easy to use online banking system as people want their money to be safe and secure. To overcome with the issues, the banks should provide more facilities and convenience to the customers by taking all steps and measures to make online transactions safer and secure for the customers.

\section{REFERENCES}

[1] Mustafa Hassan Mohammad Adam,] "Electronic Banking Problems and Opportunities: The Sudanese Context" European Journal of Business and Management www.iiste.org ISSN 2222-1905 (Paper) ISSN 2222-2839 (Online) Vol.5, No.22, 2013.

[2] Tahir Masood Qureshi, "Customer Acceptance of Online Banking in Developing Economies", Journal of Internet Banking and Commerce, April 2008, vol. 13, no.1. 
[3] Mohammed Ben-Jadeed; Alfonso Molina, "The Emergence and Evolution of e-Banking in Saudi Arabia: The Case of Samba Financial”, FRONTIERS OF E-BUSINESS RESEARCH 2004.

[4] Anju Dagar, "Online Banking: Benefits and Related Issues", IRACST - International Journal of Commerce, Business and Management (IJCBM), ISSN: 2319-2828, Vol. 3, No. 5, October 2014.

[5] Jayshree Chavan, "Internet banking- Benefits and Challenges in an Emerging Economy", International Journal of Research in Business Management (IJRBM)Vol. 1, Issue 1, June 2013, 19-26, (C Impact Journals.

[6] Andrew Musiime and Malinga Ramadhan, "Internet banking, consumer adoption and customer satisfaction", African Journal of Marketing Management Vol. 3(10), pp. 261-269, October 2011, ISSN 2141-2421 (C)2011 Academic Journals.

[7] Bader M Almohaimmeed, "Customer Behavior towards Internet Banking: A Study of the Dormant Users of Saudi Arabia" University of Birmingham, January2012.

[8]Leela Kathi, "A Study of Awareness of E-Banking Services in India ,Aurora Technological Research Institute ,February 24, 2013.

[9] Shilpan Vyas ,"Impact of E-Banking on Traditional Banking Services” arxiv.org/pdf/1209.2368.

[10] Saudi Arabian Banks on the Web Sajjad M. Jasimuddin.

[11] http://www.slideshare.net/Manisha_D_Vaghela13/traditional-online-banking.

[12] http://www.slideshare.net/nitin4u009/ebanking-15520564.

[13]http://in.reuters.com/article/benefits-and-drawbacks-of-internet-banki-idINDEE87106320120802.

[14] Saudi Arabian Monetary Agency, E-Banking RULES, Banking Technology department, APRIL 20.

Citation: Dr. Hajera Fatima Khan, "E-Banking: Benefits and Related Issues". American Research Journal of Business and Management; V3, I1; pp:1-7.

Copyright (c) 2017 Dr. Hajera Fatima Khan, This is an open access article distributed under the Creative Commons Attribution License, which permits unrestricted use, distribution, and reproduction in any medium, provided the original work is properly cited. 